\title{
Late glacial and Holocene marine records from the Independence Fjord and Wandel Sea regions, North Greenland
}

\author{
Niels Nørgaard-Pedersen ${ }^{1}$, Naja Mikkelsen ${ }^{1}$ \& Yngve Kristoffersen² \\ 1 Geological Survey of Denmark and Greenland, Øster Voldgade 10, DK-1350 Copenhagen K, Denmark \\ 2 Department of Earth Science, University of Bergen, Allégaten 41, N0-5007 Bergen, Norway
}

\section{Keywords}

foraminifera; glaciomarine; Holocene; late glacial; North Greenland.

\section{Correspondence}

N. Nørgaard-Pedersen, Geological Survey of Denmark and Greenland, Øster Voldgade 10 DK-1350 Copenhagen K, Denmark.

E-mail: nnp@geus.dk

doi:10.1111/j.1751-8369.2008.00065.x

\begin{abstract}
The first marine sediment cores from the unexplored Independence Fjord system and the Wandel Sea, North Greenland, have been investigated to reveal the glacial marine history of the region. Two key sites in the Independence Fjord system, and an earlier analysed site from the Wandel Sea continental slope, off the mouth of Independence Fjord, are presented. The Independence Fjord sites reveal an early Holocene record (10.0-8.9 Kya) of fine-grained reddish muds with calcareous microfossils, dominated by the benthic foraminifera Cassidulina neoteretis. We suggest that a semi-permanent fast ice cover characterized the region in the early Holocene, and that the deeper troughs in the mouth region of the Independence Fjord system were intruded by subsurface Atlantic water. A stiff diamicton, at least $1.3 \mathrm{~m}$ thick, with coal and sandstone clasts of mainly local origin, and a 0.5 -m-thick Holocene cover, are found in one of the sites. The diamicton is assumed to represent a subglacial till predating the early Holocene sediments ( $>10 \mathrm{Kya}$ ). Shallow seismic records off the mouth of Independence Fjord reveal kilometre-sized troughs with signs of glacial erosion, till deposition and a Holocene glaciomarine deposition. These features could indicate that glacial ice debouching from the Independence Fjord system at some time during the last glacial period extended to the mid-outer Wandel Sea shelf. Data from a high-resolution sediment core previously retrieved from the adjacent Wandel Sea slope indicate that the maximum ice sheet advance in this area culminated about 25-20 Kya.
\end{abstract}

The Wandel Sea constitutes the 150-km-wide entrance to the Independence and Danmark fjords, herafter referred to as the Independence Fjord system (Fig. 1). This remote region in northern Greenland became known through the travels of, for example, Robert Peary, the Denmark Expedition (Amdrup 1913) and expeditions by Lauge Koch (Koch 1928a, b) early in the 20th century. Since 1975, Station Nord, a Danish military base at the west side of Kronprins Christian Land, has served as a logistic base for expeditions to the area (Fig. la).

The region has been studied little owing to its inaccessibility, and the fjords are almost unexplored because they are covered by semi-permanent fast ice. Onshore studies of raised marine and lacustrine deposits reveal fragmentary information about the former glacial history, the development of the last deglaciation and the Holocene period (Funder 1989; Funder \& Hansen 1996; Bennike \& Björck 2002). These studies indicate that the late Weich- selian ice cover over north-east Greenland was relatively thin, and was characterized by extensive ice shelves along the coast (Funder 1989). It has been suggested that ice streams draining through the Independence Fjord system extended some distance out onto the Wandel Sea shelf (Funder \& Hansen 1996), but a lack of data from marine sites has hitherto not permitted a detailed reconstruction. The deglaciation history of the region reflects the successive withdrawal of the ice sheet margin before 10 Kya.

This study presents the first data from marine sediment cores retrieved in the Wandel Sea-Independence Fjord region. Our objectives are to study the late glacialHolocene development of the region. Relevant sediment echo sounding records from the shelf region further offshore (Krause 1998) are integrated, as well as previously analysed data from a sediment core retrieved in the eastern Wandel Sea slope region (Nørgaard-Pedersen et al. 2003). 
(a)

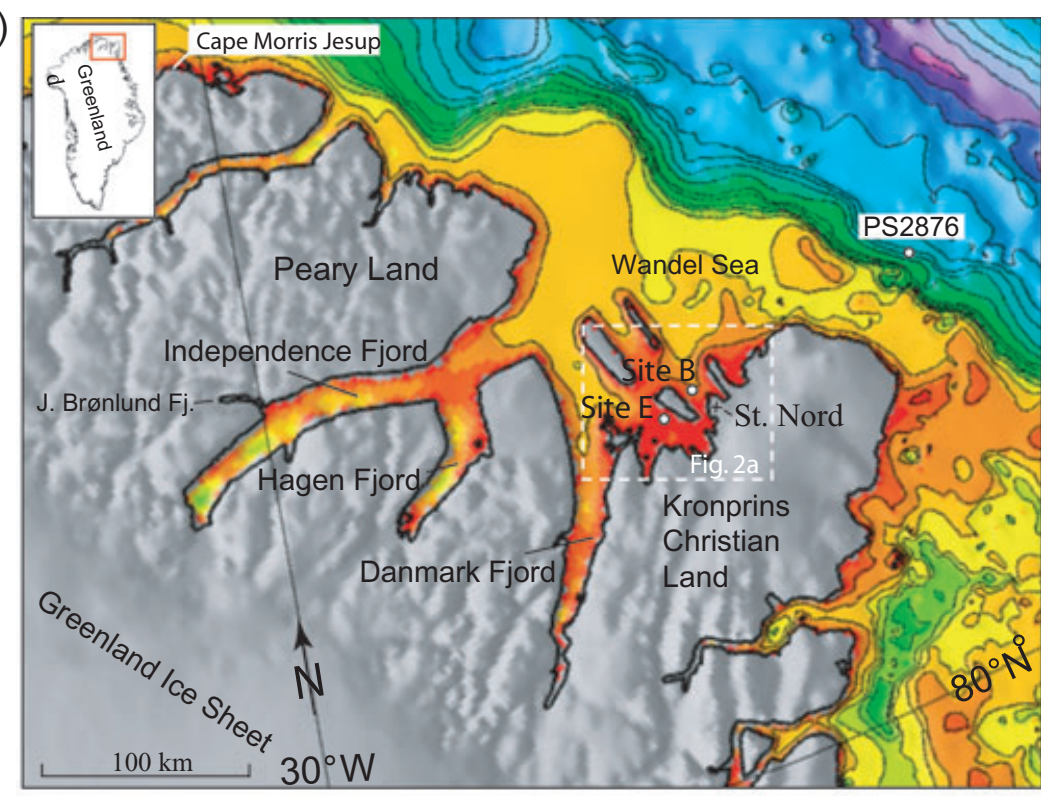

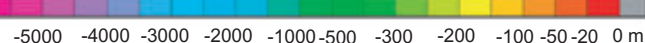

(b)

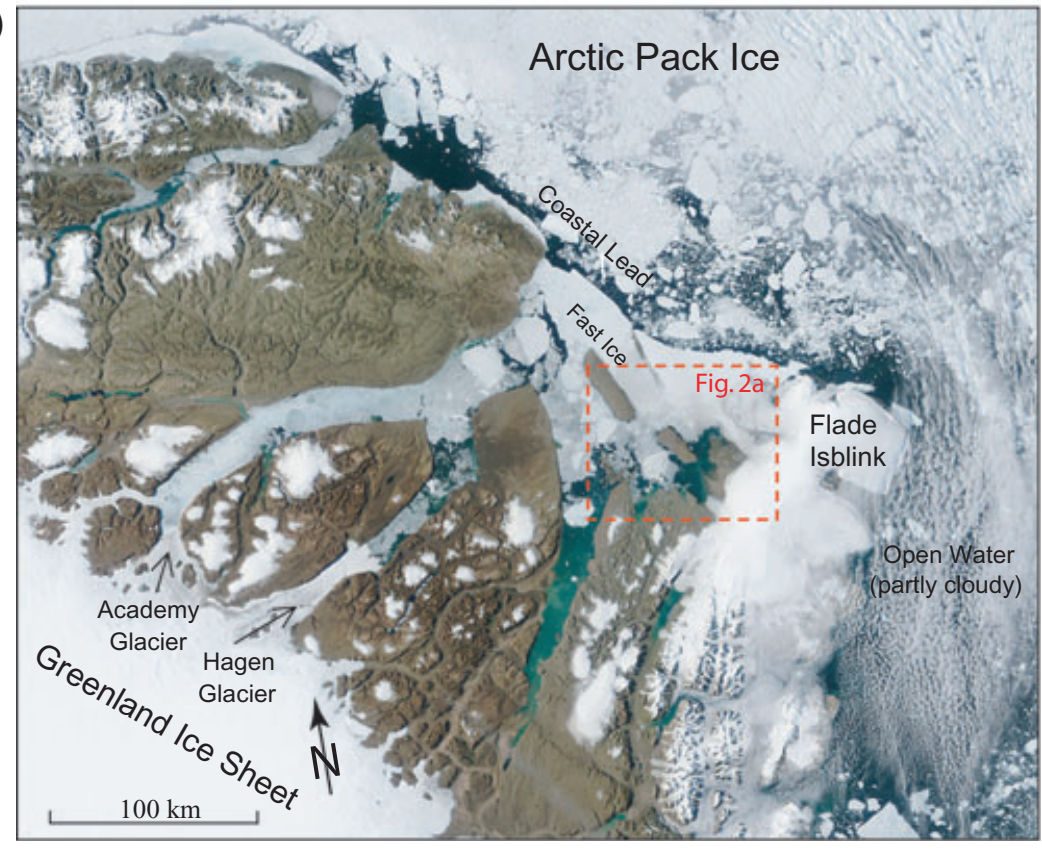

Fig. 1 (a) Bathymetric map of the Independence Fjord system and Wandel Sea (map from Jakobsson \& Cherkis 2001). The framed area indicates the study area shown in Fig. 2a. (b) TERRA/MODIS satellite photograph from 16/8/06 of the same area shown in (a). Fast ice is present in the outer parts of the Independence Fjord system, and constitutes a barrier to the open water lead extending for several hundreds of kilometres along northern Greenland. In most of Danmark Fjord, and in the area immediately to the west of Station Nord, open water with a few large ice floes can be observed. The framed area indicates the study area shown in Fig. 2 a. (Credit: Jacques Descloitres, MODIS Land Rapid Response Team, Goddard Space Flight Center, NASA.)

\section{Study area}

\section{Climate, sea ice and ice caps}

The climatic conditions in this coastal area are characterized as cold and dry (Funder et al. 1998). The mean annual temperature is about $-16.5^{\circ} \mathrm{C}$, with a mean July air temperature of about $3^{\circ} \mathrm{C}$. Further inland, in the large ice-free areas, however, summer temperatures are slightly higher. The mean annual precipitation is about $200 \mathrm{~mm}$ per year.

The Independence Fjord system is characterized by semi-permanent fast ice that meets the Arctic Ocean pack ice across the Wandel Sea shelf. A coastal lead may, during summer periods with southerly winds, open between the fast ice edge and the Arctic pack ice (Fig. 1b). 
The coastal lead is typically connected to open water of the western Fram Strait, and can occasionally be observed to show open water with scattered ice floes all the way to Cape Morris Jesup, the northernmost point of Greenland. During the occasional break-up of fast ice in the fjord area, the outermost fjord region between eastern Peary Land and northern Kronprins Christian Land (Fig. 1) can be observed to be the last stronghold before the break-up of fast ice, and the establishment of an open water connection to the Arctic Ocean. The reason for this situation is probably the anchor point effect of the Prinsesse Islands (Prinsesse Thyra, Prinsesse Dagmar and Prinsesse Margrethe islands; Fig. 2a), as well as the effect of compressional shear ice dynamics and the predominance of southeastward moving Arctic pack ice. Ice floes as big as 20 or $30 \mathrm{~km}$ accross can be observed as characteristic whitish and snow-covered features on satellite photographs (Fig. 1b). During periods of reduced sea-ice cover, large floes are observed as being almost stationary for extended periods, indicating that they are grounded in relatively shallow waters. No oceanographic data are available from the Independence Fjord system. For the outer Wandel Sea, a general south-eastward drift of polar surface water and subsurface (>150-200 m) modified Atlantic Water can be inferred (Anderson et al. 1994; Rudels et al. 1994).

The northern limit of the Greenland Ice Sheet is located about $250 \mathrm{~km}$ south-west of the study area, feeding large glaciers like the Academy Glacier and Hagen Glacier draining into the inner fjord regions of the Independence Fjord system (Fig. 1b). Kronprins Christian Land, east of Station Nord, is partly covered by the approximately $70-\mathrm{km}^{2}$ ice cap Flade Isblink (Fig. lb). In general, the glaciers in the region are not very active, and rates of both accumulation and ablation over the northern part of the Greenland Ice Sheet are considered to be low (Reeh 1989; Reeh et al. 1997).

\section{Geology}

The ice-free areas of northern Kronprins Christian Land, east of the study area, are composed of alternating marine and continental late Jurassic to early Paleogene sedimentary rocks (Henriksen 1992). These deposits are part of the Wandel Sea strike-slip mobile belt that is bounded by a fault zone oriented ESE-WNW from Kronprins Christian Land to Peary Land (Håkansson \& Pedersen 2001). Immediately north-west of the fault zone, the Prinsesse Islands and the southern part of the ice-free area, south of Station Nord, are composed of Paleocene-earliest Eocene alternating sandstones and shales, with plant remains and coal seams. The land area south-west of the fault zone, dissected by the Independence Fjord and Denmark Fjord, is composed of undeformed Proterozoic sandstones and siltstones injected by mainly basic igneous rocks, and overlain by lower Paleozoic platform carbonates, alternating with sandstones and shales (Henriksen 1992).

North Greenland has been less affected by glacial erosion than other parts of Greenland (Henriksen 1992). Consequently, thick and extensive accumulations of Quaternary sediments are preserved along fjords and coasts, and in the major valleys (Funder 1989). Patches of coarse sandy till and scattered glacial erratics are ubiquitous. Till forms a continuous cover in areas south of Independence Fjord and along the east coast of Peary Land. It has been suggested that the late Weichselian ice cover over north-east Greenland was relatively thin, and that it was characterized by extensive ice shelves along the coast (Funder 1989). The deglaciation history of the region reflects the successive withdrawal of the Quaternary ice before 10 Kya. Relative sea level curves of the last $10 \mathrm{Ky}$ for the region reveal a fairly uniform uplift throughout the Holocene, with ca. $70 \mathrm{~m}$ height at the 10-Kya marine limit (Bennike \& Weidick 2001). The shrinkage of the ice sheet and of local ice caps is demonstrated by numerous moraines along fjords and valleys (Funder 1989). At about $10 \mathrm{Kya}$, the greater part of the large Independence Fjord system was free of ice, as shown by ${ }^{14} \mathrm{C}$ dates of mollusc shells from near the mouth of Jørgen Brønlund Fjord (Fig. la) (Bennike 1987; Bennike \& Björck 2002). At $7 \mathrm{Kya}$, most major glaciers seem to have achieved their present extent, and by 6 Kya at least some glaciers were up to $20 \mathrm{~km}$ behind their present front. For the eastern coast of Kronprins Christian Land, Bennike \& Weidick (2001) indicate minimum dates between 9.1 and 11.0 Kya for the last deglaciation.

\section{Field and laboratory methods}

The fieldwork was carried out in May 2006 from twoperson camps moved by skidoos on the fast-ice to the east and west of Prinsesse Dagmar Island (Figs. 1a, 2a, 3). Ice thicknesses encountered during the site survey were in the range $0.40-2.25 \mathrm{~m}$. Sediment coring and depth recording were performed through holes drilled in the sea ice with a $30-\mathrm{cm}$ ice auger. Sediment coring was performed with a new prototype coring system, developed by Y. Kristoffersen, that allows re-entry and includes a hammer function, thereby increasing recovery, and making it possible to penetrate stiff diamictic material. The corer had a 1-m-long steel barrel with an inner core liner diameter of $10 \mathrm{~cm}$. The corer was equipped with an underwater video camera in order to control and observe the re-entry process. In order to construct composite sections of the re-entry core sections recovered, the penetration depth below the sediment-water interface 
(a)

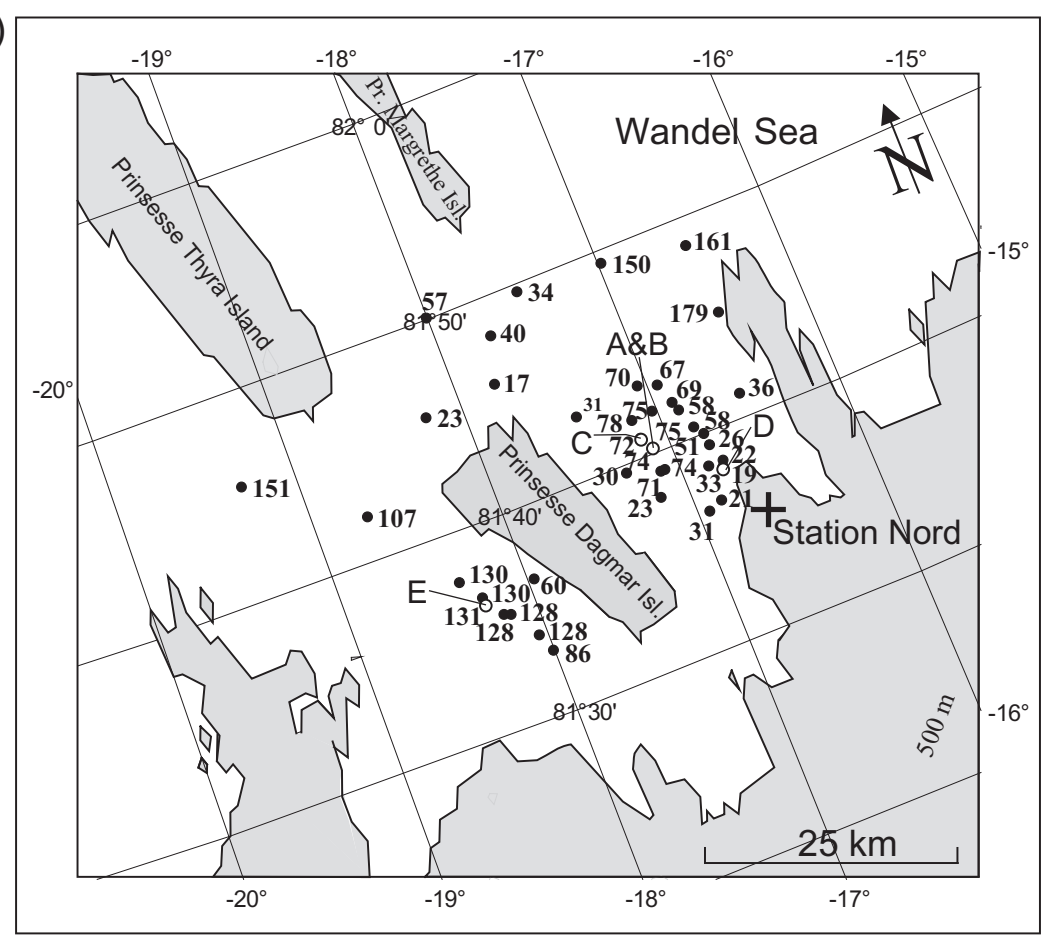

(b)

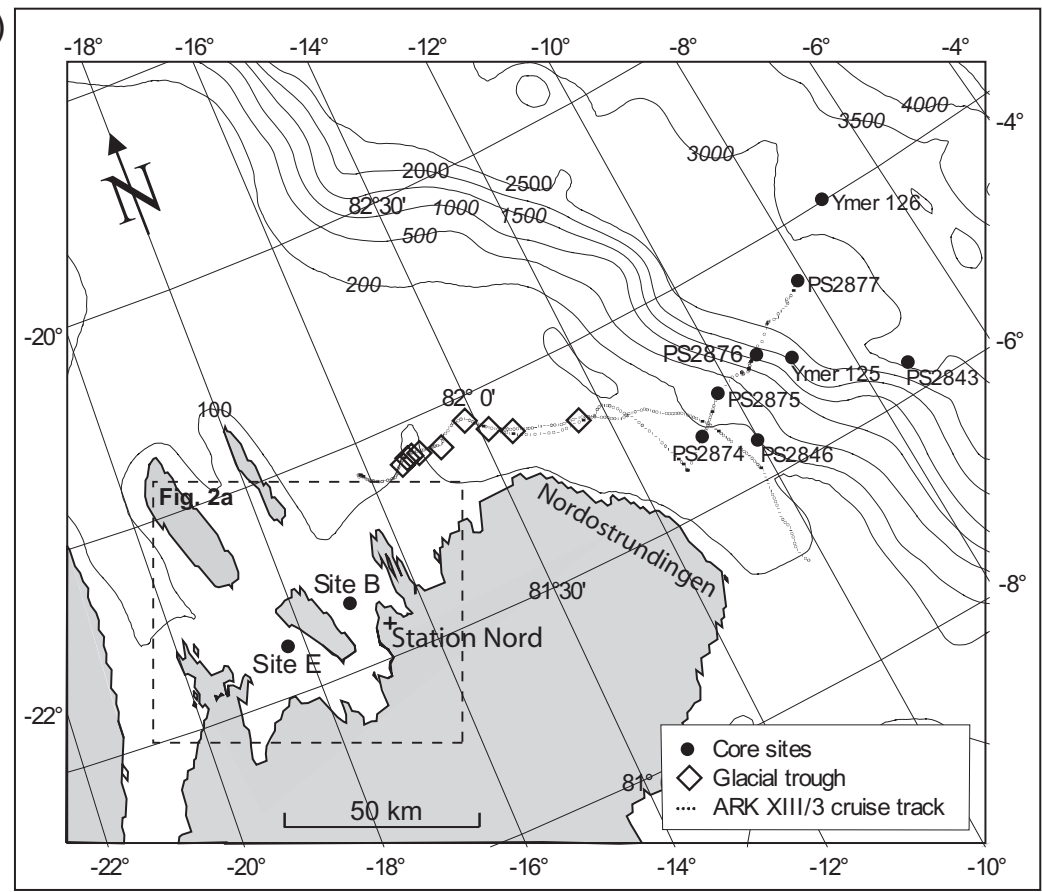

Fig. 2 (a) The study area east and west of Prinsesse Dagmar Island (core sites A-E) with water depths (in metres) indicated (Forsberg unpubl. data, and data from this study). (b) Location of sediment core sites referred to in the text (RV Polarstern cores [prefix PS] and RV Ymer cores [prefix YMER]). On the Wandel Sea shelf, about $20 \mathrm{~km}$ from the coast of Nordostrundingen, glacially eroded troughs with possible late glacial and Holocene fill are marked by diamonds. The framed area indicates the study area shown in detail in (a). was measured, in addition to the length of the separate core sections measured after opening the cores (downfall sediment not included). Composite sections of up to $1.75 \mathrm{~m}$ were recovered (Table 1 ).

Magnetic susceptibility was measured on whole core sections in 1-cm steps with a Bartington Ltd. MS2C core loop sensor (volume specific). Selected sediment cores were split into two halves, and were routinely photographed and described with respect to sedimentary/ biogenic structures, grain size and sediment colour (Munsell Soil Color Chart). The core sections were subsampled with syringes $(1-\mathrm{cm}$ diameter) every $2-5 \mathrm{~cm}$. 
One set of fixed volume samples $\left(4 \mathrm{~cm}^{3}\right)$ was weighed before and after freeze-drying, and water content and dry bulk density were calculated. Afterwards, the samples were wet-sieved $(>63 \mu \mathrm{m}$ and $>1 \mathrm{~mm})$. Additionally, bulk sediment samples were measured with a Malvern

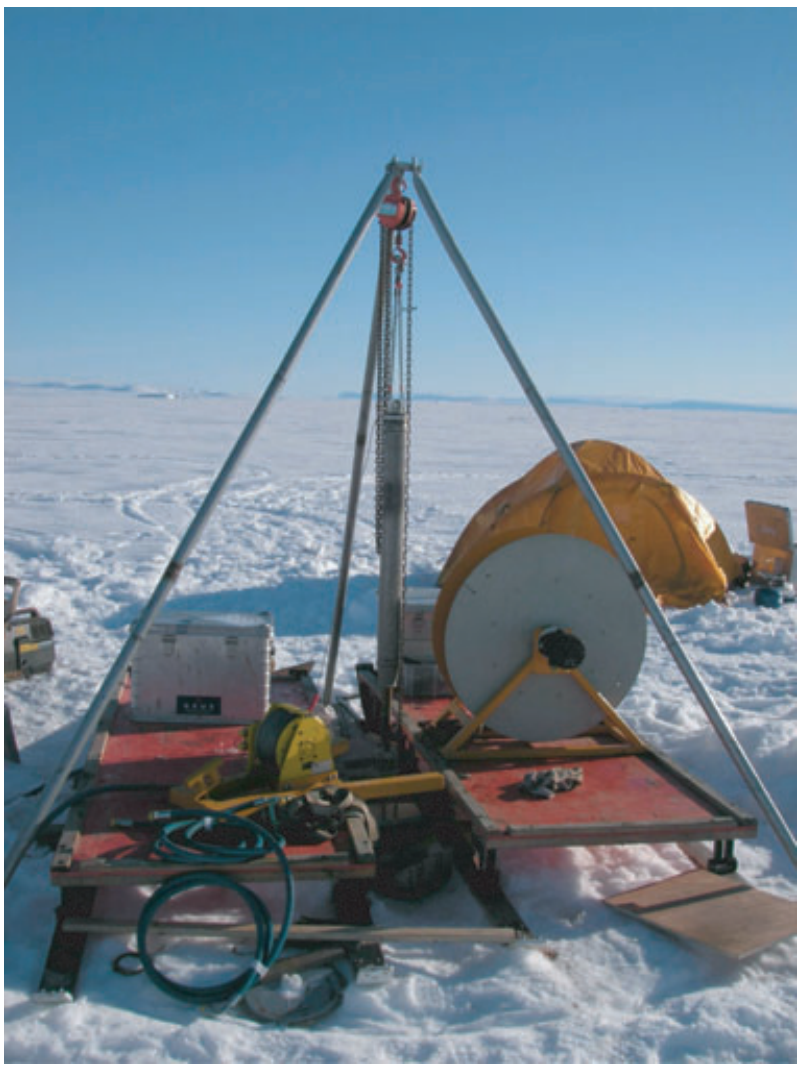

Fig. 3 Coring set-up with the shelter tent removed.
Mastersizer 2000 laser particle size analyser. Before the measurements, the samples were dispersed with natriumpyrophosphate $\left(0.01 \mathrm{M} \mathrm{Na} \mathrm{Na}_{2} \mathrm{O}_{7} \cdot 10 \mathrm{H}_{2} \mathrm{O}\right)$, and were then treated in an ultrasonic bath for $2 \mathrm{~min}$. The fraction $0.3-1700 \mu \mathrm{m}$ was analysed, and the cumulative volume (\%) determined for about 62 specific grain-size intervals. The mean particle size was also calculated (see McCave et al. 1995). Accelerator mass spectrometry (AMS) ${ }^{14} \mathrm{C}$ dates were obtained from benthic foraminifera, as well as from a relatively minor quantity of planktic foraminifera and ostracods. The dates have been reservoir corrected by subtracting 550 years (Tauber \& Funder 1975), and calibrated ages have been calculated according to CALIB 4.0 (Stuiver \& Reimer 1993) using the Hughen et al. (2004) calibration data set. In core section \#15 (site E), the abundances of planktic and benthic (calcareous) foraminifera per gram sediment were determined on the grain-size fraction 100-1000 $\mu \mathrm{m}$ by counting the number of specimens in split samples. In addition, calcareous benthic foraminifera species assemblages were determined for representative sample splits at selected depth intervals with elevated numbers of specimens.

\section{Results}

The bathymetry of the Independence Fjord system is almost unknown, but a general outline is given in the International bathymetric chart of the Arctic Ocean (Jakobsson \& Cherkis 2001; see also Jakobsson et al. 2000; Fig. la). During an earlier reconnaissance trip (Forsberg unpubl. data), and during the 2006 field campaign, bathymetric data were compiled for the study region in order to locate potential coring sites (Fig. 2a).

Table 1 Coring stations. Composite depths are indicated at site B, where the re-entry technique was successful. As a result of sediment downfall in the core hole, the total composite depth is less than the sum of the lengths of the separate core sections recovered.

\begin{tabular}{|c|c|c|c|c|c|c|}
\hline Site & Core section no. & $\begin{array}{l}\text { Latitude } \\
{ }^{\circ} \mathrm{N}\end{array}$ & $\begin{array}{l}\text { Longitude } \\
{ }^{\circ} \mathrm{W}\end{array}$ & Water depth (m) & Recovery (cm) & Composite depth $(\mathrm{cm})$ \\
\hline$A$ & $\# 1$ & 81.65143 & 17.07650 & 74 & 15 & - \\
\hline$B$ & \#2 & 81.65143 & 17.07549 & 74 & 35 & $0-35$ \\
\hline B & \#3 & - & - & 74 & 49 & $35-75$ \\
\hline B & \#4 & - & - & 74 & 84 & $20-104$ \\
\hline$B$ & \#5 & - & - & 74 & 55 & $104-137$ \\
\hline B & \#6 & - & - & 74 & 28 & $137-157$ \\
\hline$B$ & \#7 & - & - & 74 & 64 & $157-175$ \\
\hline C & \#8 & 81.68187 & 17.13701 & 72 & 15 & - \\
\hline$D$ & \#9 & 81.63636 & 16.77437 & 19 & 0 & - \\
\hline E & $\# 10$ & 81.60235 & 18.26000 & 131 & 0 & - \\
\hline$E$ & $\# 11$ & - & - & 131 & 13 & - \\
\hline E & $\# 12$ & - & - & 131 & 36 & - \\
\hline E & $\# 13$ & - & - & 131 & 67 & 40-107 \\
\hline$E$ & $\# 14$ & - & - & 130 & 50 & - \\
\hline$E$ & \#15 & - & - & 130 & 105 & - \\
\hline
\end{tabular}




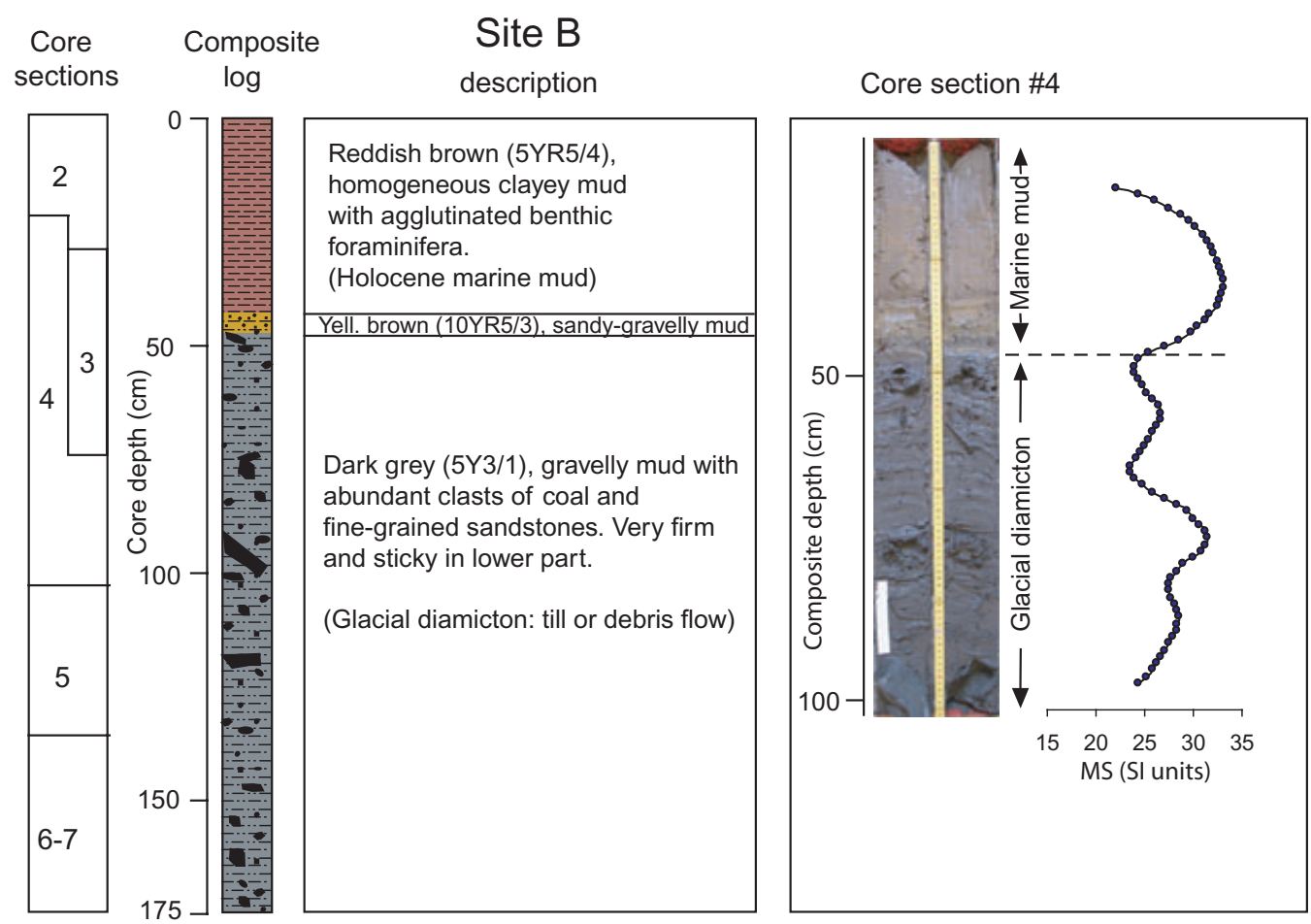

Fig. 4 Composite lithological log of core sections $2-7$ recovered at site B, as well as a photographic and magnetic susceptibility record $\left(\times 10^{-6} \mathrm{SI}\right)$ of core section 4.

\section{Core data}

Sediment cores were retrieved from five coring sites (A-E; Table 1), and of these, two key sites (B and E) are described below.

Site B is located at a water depth of $74 \mathrm{~m}$ at the eastern side of Prinsesse Dagmar Island and west of Flade Isblink (Fig. 2; Table 1). At this site six core sections were retrieved through re-entry, resulting in a 1.75 -m-long composite core (Fig. 4). The core is composed of a dark greyish diamicton, overlain by marine mud with agglutinated foraminifera, but with no calcareous microfossils. The dark grey $(5 \mathrm{Y} 3 / 1)$ diamicton is a matrix-supported, stiff, gravelly-sandy mud with a sand content of about $30 \%(>63 \mu \mathrm{m})$. The clasts are up to $10 \mathrm{~cm}$ in diameter and are composed mainly of fine-grained sandstone, with some glauconite and coal fragments. Palynological examination of the coal material indicates a Paleoceneearliest Eocene age of the eroded material (N.E. Poulsen, pers. comm. 2007). The diamicton is overlain by a $5-\mathrm{cm}$ thick yellowish brown (10YR5/3) mud layer with abundant coarse clasts of sand-granule size (0.5$10 \mathrm{~mm} \varnothing$ ) (including agglutinated foraminifera) with an iron-manganese coating. The overlying ca. $40-\mathrm{cm}$ top unit is composed of reddish brown (5YR5/4), clayey mud
( $1-2 \% ;>63 \mu \mathrm{m})$, with only a few larger ice-rafted debris (IRD) grains. The common occurrence of the agglutinated foraminifera Reophax pilulifer indicates a marine origin of the sediment. The magnetic susceptibility (MS) values of the core sections are quite low $\left(20-33 \times 10^{-6}\right.$ SI; Fig. 4). It is, however, characteristic that the much finer-grained reddish brown muds show MS values about $5 \times 10^{-6} \mathrm{SI}$ units higher than the grey diamicton.

Site E, west of Prinsesse Dagmar Island, is located at a water depth of $130 \mathrm{~m}$ and comprises six core sections (cores 10-15) offset laterally $\pm 1 \mathrm{~m}$ (Fig. 2; Table 1). At this site, the re-entry of coring holes was not succesful, and in addition over-penetration of core section 13 caused the topmost $50 \mathrm{~cm}$ of the sediment column to be injected into the core weight. The three core sections presented (13, 14 and 15; Fig. 5) represent a ca. 1-m composite section composed of reddish (5YR5/3), clayey and silty marine mud, with 5-10-cm-thick intercalations of greyish (10YR4/1) or yellowish (10YR5/3), silty to clayey mud with sharp lower boundaries and oxidized reddish brown tops. Well-preserved calcareous benthic foraminifera and subordinate planktic foraminifera are found in low quantities in nearly all samples. A few horizons, $2-3 \mathrm{~cm}$ thick, are characterized by higher quantities of foraminifera (250-500 benthic specimens 


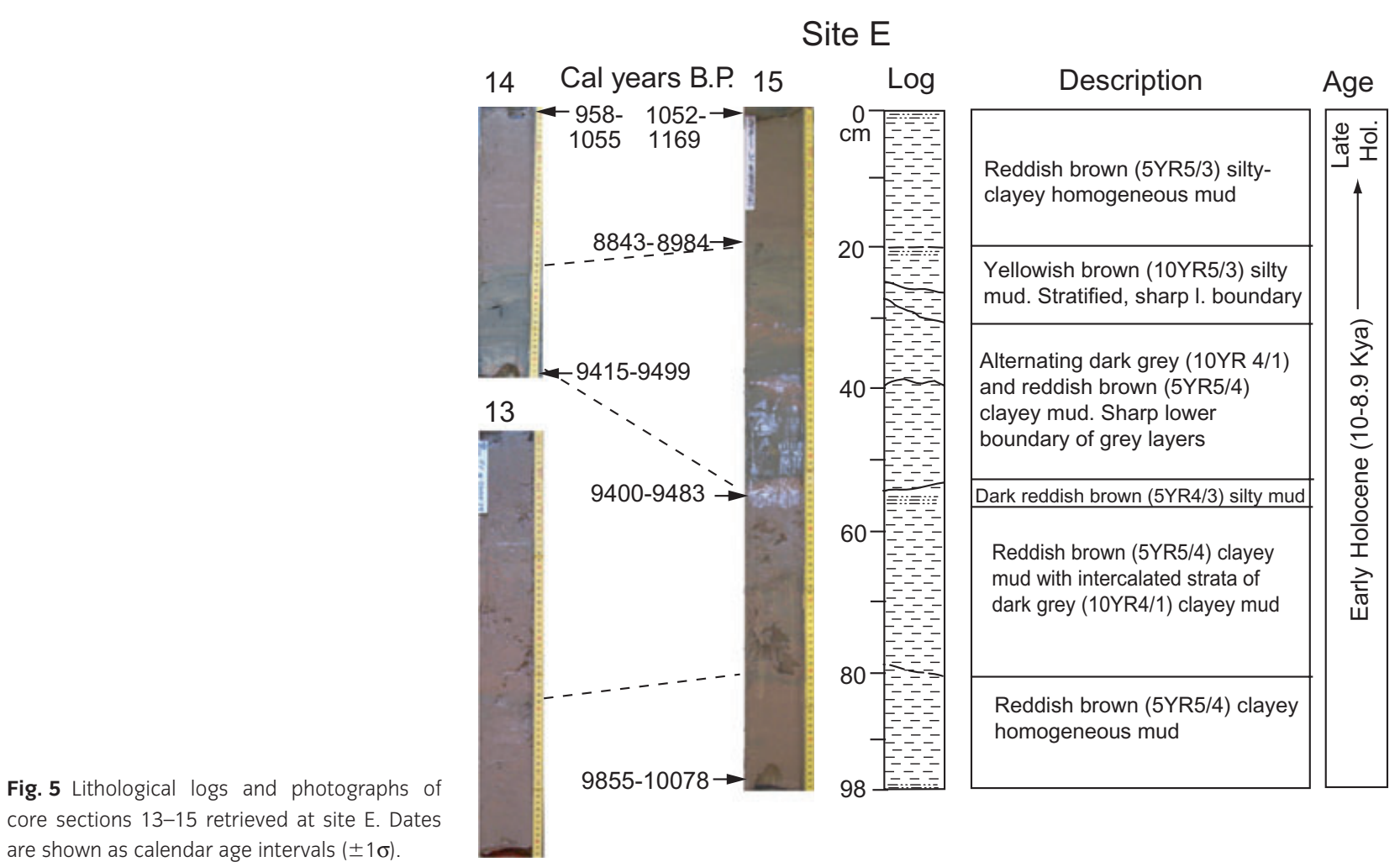

per gram of sediment; Fig. 6), agglutinated foraminifera, ostracods and sponge spicules. Material from the microfossil-rich horizons was sampled for AMS ${ }^{14} \mathrm{C}$ dating and determination of benthic foraminifera (calcareous) species assemblages. The radiocarbon dates reveal that the recovered core sections from site E, apart from the topmost section $(\leq 19 \mathrm{~cm})$, have an early Holocene age of between ca. 10.0 and $8.9 \mathrm{Ky}$ (Figs. 5 and 6; Table 2). Samples from $1-\mathrm{cm}$ depth in core sections 14 and 15 provided ages of 1.0-1.1 Ky.

The calcareous benthic foraminifera Cassidulina neoteretis is dominant $(84.5-88.5 \%)$ in the species assemblage throughout the section (Table 3 ). Cassidulina reniforme, Elphidium excavatum (forma clavata) and Cibicidoides sp. are subordinate species. The planktic foraminifera assemblage consists of almost $100 \%$ polar species Neogloboquadrina pachyderma (s). Planktic foraminifera are rare in the section below $21 \mathrm{~cm}$, but are found more abundantly in the top section (Fig. 6). Unilocular and multilocular spherical tests of the agglutinated benthic foraminifera Reophax pilulifer occur commonly in some levels.

Wet sieving and detailed grain size distribution data on core section 15 reveal the very fine-grained character of the marine sediment (Fig. 6) that, with few exceptions, is totally devoid of coarser IRD $(>1000 \mu \mathrm{m})$. The intervals
$19-21 \mathrm{~cm}$ and $56-58 \mathrm{~cm}$ show peak values of up to $6 \%$ of grains that are $>63 \mu \mathrm{m}$ in size (maximum content of foraminifera and lithic grains). The grain size distribution data reveal mean grain sizes of about 3-6 $\mu \mathrm{m}$ (close to the $2-\mu \mathrm{m}$ clay-silt division), with slightly elevated values in the section above $50 \mathrm{~cm}$. The lower part (below $54 \mathrm{~cm}$ ) of core section 15 has magnetic susceptibility values of $80-110 \times 10^{-6} \mathrm{SI}$, followed by an intermediate section $(20-54 \mathrm{~cm})$ with MS values of only $25-35 \times 10^{-6}$ SI. The sediments in the uppermost $20 \mathrm{~cm}$ have MS values of up to $56 \times 10^{-6}$ SI. A similar tripartite MS record is evident in the composite core of sections 13 and 14 .

\section{Discussion}

The first marine sediment cores ever recovered from the outer Independence Fjord system in North Greenland have been investigated. In cores retrieved west of Prinsesse Dagmar Island (site E), an early Holocene marine sediment record is documented. This record, which has an age of about 8.9-10.0 Ky, consists of reddish brown clayey/silty mud, with greyish intercalations and horizons enriched in calcareous benthic foraminifera, with rare planktic foraminifera, ostracods and sponge spicules. Two core top dates in the range 1.0-1.1 Kya 

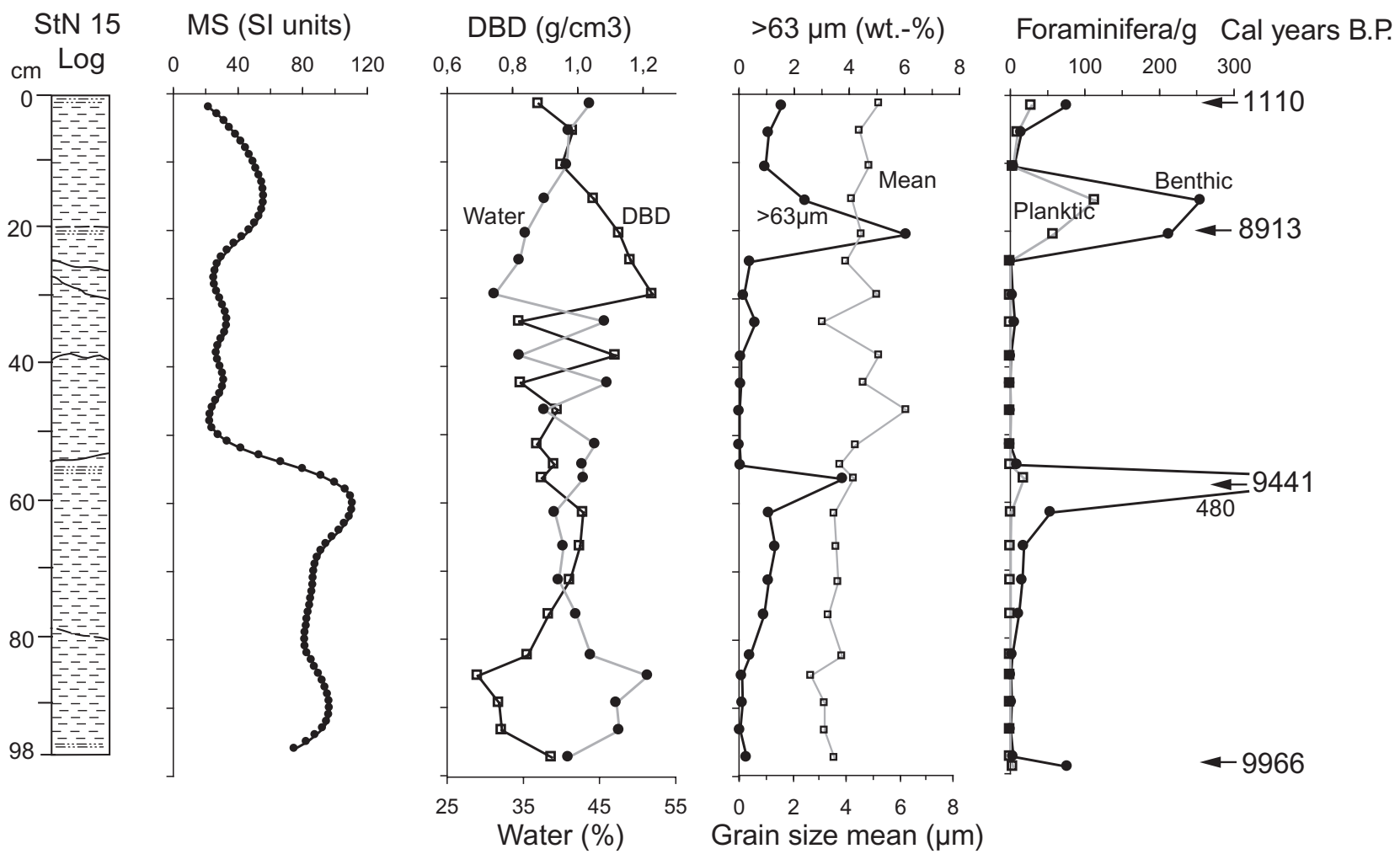

Fig. 6 Magnetic susceptibility $\left(\times 10^{-6} \mathrm{SI}\right)$, water content, dry bulk density, coarse fraction content $(>63 \mu \mathrm{m})$, mean grain size $(\mu \mathrm{m})$, and benthic- and planktic-foraminifera abundance in core section 15. The dated horizons enriched in calcareous benthic and planktic foraminifera are characteristically $<3 \mathrm{~cm}$ thick.

Table 2 Accelerator mass spectrometry (AMS) ${ }^{14} \mathrm{C}$ dates, and calibrated age range and mean (CALIB 4.0; Stuiver \& Reimer 1993; Hughen et al. 2004), from core sections 14 and 15. A reservoir correction (res. corr) of 550 years ( $\Delta r=150$ years) was used (Tauber \& Funder 1975).

\begin{tabular}{|c|c|c|c|c|c|}
\hline $\begin{array}{l}\text { Core sect. } \\
\text { no./depth }(\mathrm{cm})\end{array}$ & Lab. no. & $\begin{array}{l}\text { AMS }{ }^{14} \mathrm{C} \text { age },{ }^{14} \mathrm{C} \text { years } \\
\text { B.P. (uncorrected age) }\end{array}$ & Dated material & $\begin{array}{l}\text { Calib. age range, } \\
( \pm 1 . \sigma) \text {, years B.P. }\end{array}$ & $\begin{array}{l}\text { Calibrated age } \\
\text { mean (years B.P.) }\end{array}$ \\
\hline$\# 14,49 \mathrm{~cm}$ & KIA31757 & $8930 \pm 50$ & Foraminifera, few ostracods & $9415-9499$ & 9457 \\
\hline$\# 14,1 \mathrm{~cm}$ & KIA31758 & $1625 \pm 30$ & Foraminifera, few ostracods & $968-1055$ & 1012 \\
\hline$\# 15,98 \mathrm{~cm}$ & KIA31759 & $9300 \pm 50$ & Foraminifera, few ostracods & 9855-10078 & 9967 \\
\hline$\# 15,57 \mathrm{~cm}$ & KIA33484 & $8910 \pm 45$ & Foraminifera & $9400-9483$ & 9442 \\
\hline$\# 15,19.5 \mathrm{~cm}$ & KIA33483 & $8475 \pm 40$ & Foraminifera & $8843-8984$ & 8914 \\
\hline$\# 15,1 \mathrm{~cm}$ & KIA31760 & $1705 \pm 50$ & Foraminifera, few ostracods & $1052-1169$ & 1111 \\
\hline
\end{tabular}

reveal that mid Holocene deposits are condensed or missing, but there is no evident sedimentary expression of a hiatus in the cores (Figs. 5, 6). The very fine-grained character of the sediment, with only a few IRD clasts of $>1000 \mu \mathrm{m}$ in size, supports a dominant deposition from suspension, and an extremely limited contribution from ice rafting of sediment. Conditions with semipermanent fast-ice cover both in the early and late Holocene presumably reduced sediment transport and sediment entraining, as well as the melt-out of ice-rafted sediments in the area (see Ó Cofaigh \& Dowdeswell 2001; Syvitski et al. 1996). The intercalated fine-grained greyish subunits with sharp lower boundaries and oxidized, reddish brown upper parts (Figs. 5, 6) possibly represent rapidly deposited density underflow events (slope failures?). Rapid deposition is also supported by relatively high water contents and sparse microfossils in these core sections. The occurrence of slightly coarsergrained reddish brown units with peak contents of benthic foraminifera and other microfossils (Figs. 5, 6) is suggested to reflect periods with more stable bottom conditions and slow suspension deposition. Based on the very limited variability of benthic foraminifera species assemblages (Table 3), it is suggested that dilution by 
Table 3 Benthic foraminifera assemblage (calcareous species) from selected intervals in core section 15, site E. Apart from the sample interval $71-72 \mathrm{~cm}$ (total 87 specimens), only intervals with sufficient specimens (>250) for quantitative analyses were counted.

\begin{tabular}{|c|c|c|c|c|c|}
\hline $\begin{array}{l}\text { Depth } \\
(\mathrm{cm})\end{array}$ & $\begin{array}{l}\text { Cassidulina } \\
\text { neoteretis } \\
(\%)\end{array}$ & $\begin{array}{l}\text { Cassidulina } \\
\text { reniforme } \\
(\%)\end{array}$ & $\begin{array}{l}\text { Elphidium } \\
\text { excavatum } \\
\text { (forma clavata) } \\
(\%)\end{array}$ & $\begin{array}{l}\text { Cibicidoides } \\
\text { lobatulus } \\
(\%)\end{array}$ & $\begin{array}{l}\text { Other } \\
(\%)\end{array}$ \\
\hline $1-2$ & 88.5 & 4.2 & 1.0 & 5.2 & 1.0 \\
\hline $15-16$ & 87.8 & 6.7 & 2.2 & 1.1 & 2.2 \\
\hline $19-20$ & 88.0 & 6.9 & 3.1 & 1.1 & 1.0 \\
\hline $56-57$ & 86.0 & 6.0 & 2.0 & 2.0 & 4.0 \\
\hline $71-72$ & 84.5 & 3.4 & 8.6 & 0.0 & 3.4 \\
\hline 97-98 & 85.4 & 6.3 & 6.3 & 0.0 & 2.1 \\
\hline
\end{tabular}

changes in sedimentation rate is the main cause for the peak occurrence of foraminifera. The benthic foraminifera $C$. neoteretis dominates the assemblages in the Holocene section of site E. This species is dominant in Holocene sediments from shelf margin troughs of the Barents and Kara seas (Polyak \& Solheim 1994; Lubinski et al. 2001), as well as in modern sediments of deep East Greenland and North Iceland troughs (Jennings et al. 2004). These areas are all characterized by the presence of Atlantic Water at depths below $200 \mathrm{~m}$ and underlying the polar surface water. Our findings indicate that chilled, slightly transformed subsurface Atlantic water was present at greater depths in the Independence Fjord system during the early Holocene and late Holocene. Because of the limited time resolution of the mid-late Holocene record, we do not know if Atlantic water advection to the area was a consistent feature during this period. The findings of planktic foraminifera N. pachyderma (s) in the layers with peak benthic foraminifera is remarkable at this relative shallow site $(130 \mathrm{~m})$, which is more than $100 \mathrm{~km}$ from the shelf margin. Life cycle requirements mean that planktic foraminifera are quite rare in shelf environments of $<150-200$-m water depths, and a more or less permanent fast-ice cover in the area should prevent in situ primary production of diatoms, the main food source for N. pachyderma (s) (Salvi et al. 2006; Hemer et al. 2007). Detailed studies from Arctic shelves only show higher abundances of planktic foraminifera in shelf margin troughs characterized by strong advection of Atlantic water masses (e.g., Hald \& Vorren 1984; Lubinski et al. 2001). Relative sea-level change implies that water depth at the site in the early Holocene was up to $70 \mathrm{~m}$ deeper than now (i.e., ca. $200 \mathrm{~m}$ ). Glacio-eustatic uplift outpaced the effect of the eustatic sea-level rise, so that relative sea level from 10-8.9 Kya fell about $15 \mathrm{~m}$ (Bennike \& Weidick 2001). Therefore, sea-level influence does not explain the observed increase of planktic foraminifera from about 10 to 8.9 Kya. The observed trend rather reflects the advection of specimens with Atlantic Water currents from a productive region further offshore (shelf margin polynya?). The common occurrence of agglutinated tests from $R$. pilulifer may also support the presence of Atlantic-sourced water, as on the BarentsKara shelf this species is restricted to oligotrophic deepwater areas (200-600 m), characterized by Atlantic water advection (Korsun et al. 1998).

The reason for the apparently very low sediment accumulation rate during the mid-late Holocene is not evident, but a likely explanation is that the influx of meltwater-derived sediments ceased after about 9 Kya.

At site B, located east of Prinsesse Dagmar Island and west of the Flade Isblink ice cap, a stiff and massive grey diamicton, at least $1.2 \mathrm{~m}$ thick, is present. The stiff character of this diamicton may indicate that it was formed as a subglacial till, although it cannot be excluded that it represents an ice proximal debris flow deposit. It is characterized by abundant coal and sandstone clasts, presumably indicating a provenance mainly from local Wandel Sea Basin sedimentary rocks. Palynological investigations show that the abundant coal fragments have a local Palaeogene source. Sandstone clasts with glauconite, however, have not been described from the region, and it is possible that they originate from Cretaceous sub-basin deposits, which are now partly covered by the Flade Isblink ice cap (L. Stemmerik, pers. comm. 2007). The diamicton is overlain by ca. $0.5 \mathrm{~m}$ of reddish brown marine mud with agglutinated benthic foraminifera $R$. pilulifer, which is also found in the Holocene core sections at site $\mathrm{E}$. The marine sediment from the shallower site $\mathrm{B}$ is devoid of calcareous microfossils, thus precluding AMS ${ }^{14} \mathrm{C}$ dating. It is likely, however, that the diamicton is older than the fine-grained Holocene sediments found in the basin south-west of Prinsesse Dagmar Island, i.e. >10 Kya. A hypothetical Holocene advance of the Flade Isblink ice cap of at least $20 \mathrm{~km}$ north-westward into the study area east of Prinsesse Dagmar Island would most likely have caused a higher influx of coarser sediment to site E. Moreover, radiocarbon dates from the Independence Fjord and Kronprins Christian Land (near Flade Isblink) region (Bennike \& Björck 2002), as well as strand line emergence curves (Bennike \& Weidick 2001), indicate a minimum date of about 10 Kya for the deglaciation of the main fjord system. The thicker Holocene sediment cover at site $\mathrm{E}$ compared with site B can be explained by the influence of local sedimentation processes and the influx of rapidly deposited density underflow units.

Bathymetric and shallow seismic data from the Wandel Sea area off Nordostrundingen (Fig. 2b) reveal extensive iceberg gouging and limited sea-bottom penetration (Krause 1998). However, on the eastern Wandel Sea 


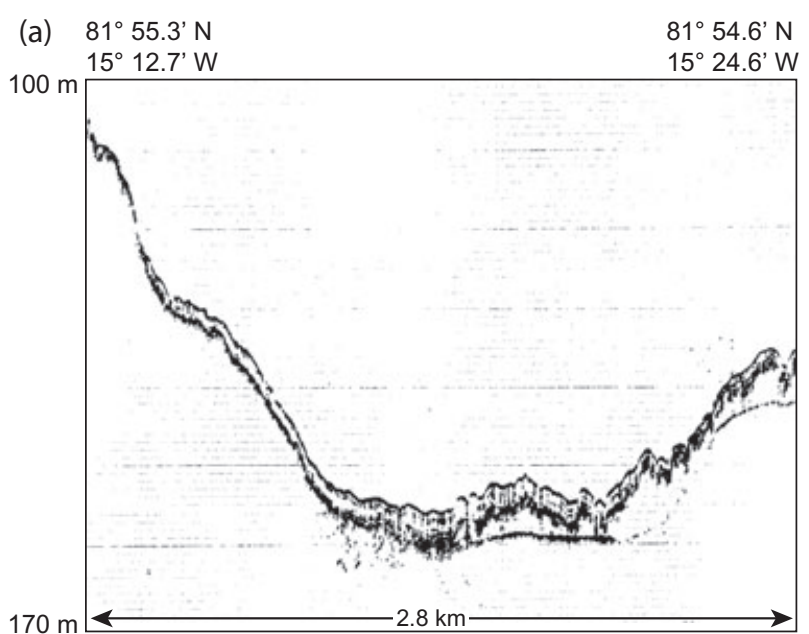

(b)

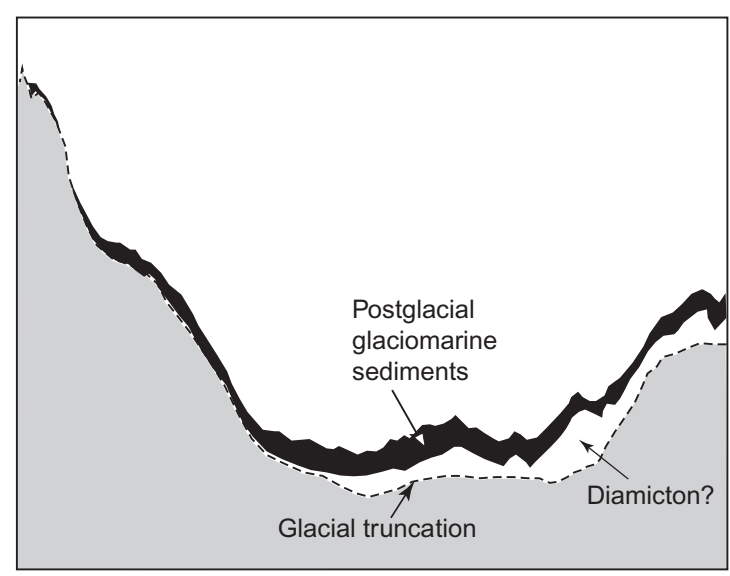

Fig. 7 (a) Parasound sediment echo sounding profile of a characteristic trough with sediment infill from the eastern Wandel Sea shelf, recorded by RV Polarstern, August 1997 (from Krause 1998), and (b) interpretation of the seismic profile.

shelf, with water depths of 100-200 m, and situated about 40-60 km north-east of site B, large troughs, up to several kilometres wide and at least $50 \mathrm{~m}$ deep, appear to be unaffected by severe ice gouging (Fig. 7). The rounded shape of a subbottom reflection suggests glacial truncation. An acoustically transparent layer (glacial till or debris flow) occurs in some of these troughs. It is overlain by a stratified unit up to several metres thick, possibly representing Holocene glaciomarine sediments. These features could well indicate that glacial ice, debouching from the Independence Fjord system at some time during the last glacial period, covered the mid-outer Wandel Sea shelf. The preservation of these troughs and the absence of extensive iceberg gouging possibly imply that they represent relatively young glacial structures. However, the present data do not allow the age to be constrained more precisely. It is therefore unclear if the deposition of the diamicton observed in site $\mathrm{B}$ is related to the same glacial advance, or if it is younger.

A well-dated record from the continental margin slope (core PS2876; water depth 1991 m; Figs. 2b, 8) to the east of the above-described sites reveal detailed information on changing last glacial conditions in the area (Nørgaard-Pedersen et al. 2003). Accumulation rates increased to maximum values of $20-40 \mathrm{~cm}$ per Ky in the period 25-20 Kya. A gravel-rich layer observed in core PS2876 (coarse fraction and magnetic susceptibility peak), and dated to about 23-22 Kya, is also found in adjacent RV Polarstern cores (Stein \& Fahl 1997; Krause 1998) and RV Ymer cores (Boström \& Thiede 1984) (Fig. 2b) from the slope region. The gravel-rich layer in PS2876 contains, among other lithologies, abundant sandstone clasts with glauconite, i.e., similar to the sandstones found in the diamicton of site $\mathrm{B}$ in the Independence Fjord system. The peak glacial accumulation rates in PS2876 are at least twice as high as estimates from several downstream (East Greenland Current) sites along the western Fram Strait continental margin (Nørgaard-Pedersen et al. 2003), and are much higher than the rates of upstream sites from the interior Arctic Ocean (Nørgaard-Pedersen et al. 2003). It is therefore suggested that most of the last glacial maximum sediment flux to site PS2876 was of local origin, i.e., from an advanced North Greenland ice sheet margin. The data from core PS2876 supports a maximum extension of a North Greenland ice sheet onto the Wandel Sea shelf during the late Weichselian, about 25-20 Kya (Fig. 9). This interpretation is also supported by IRD provenance data from the western Fram Strait core PS1230 (Darby et al. 2002), showing the most prominent peak of iron oxide grains matched to North Greenland sources at about 23 Kya. Previous land-based studies indicate that the late Weichselian ice cover over North Greenland was relatively thin, and ice movement appears to have been constrained by local topography, with ice tongues debouching from fjords (Funder 1989; Funder \& Hansen 1996).

The deglaciation of the Wandel Sea shelf, and the withdrawal of the glacier fronts to the main fjord system, may have followed a rapid sea level rise during the early part of the last deglaciation (Termination Ia?), thereby moving the main depocentres into the fjords (Fig. 9). The early Holocene marine deposits (10-8.9 Ky) found to have had high accumulation rates south-west of Prinsesse Dagmar Island are only slightly younger than the earliest dated postglacial material (11-9.7 Ky) in the area (Bennike \& Björck 2002). Additional site surveys, and deeper drilling of the fjord system and shelf troughs, may in the future, however, reveal more accurate data on the last 


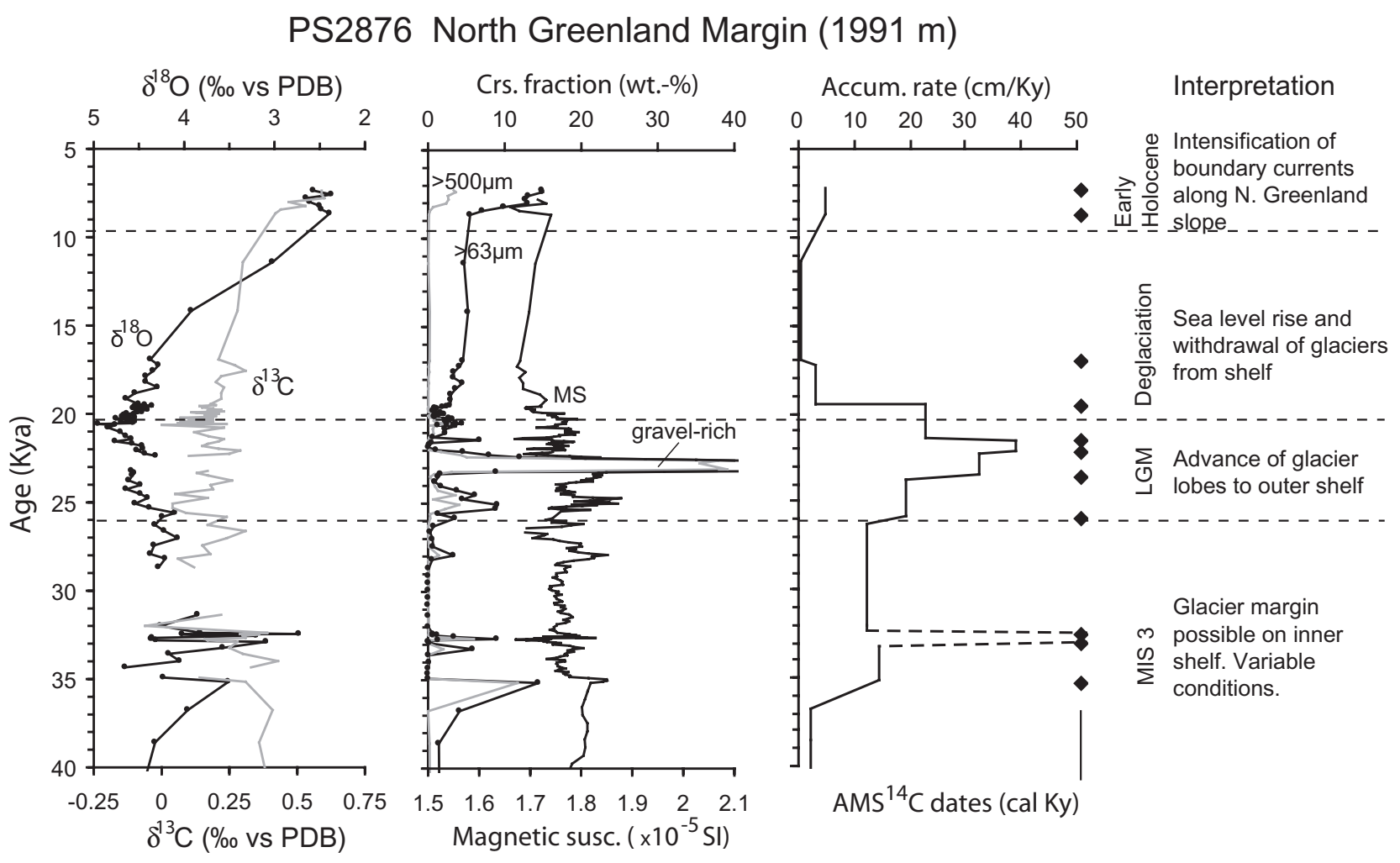

Fig. 8 The 5-40-Kya record of core PS2876 from the slope of the eastern Wandel Sea, off Nordostrundingen. The core was retrieved by RV Polarstern, August 1997 (Krause 1998; Nørgaard-Pedersen 1998; Nørgaard-Pedersen et al. 2003). The age model for the basal part of the record shown is based on an accelerator mass spectrometry (AMS) ${ }^{14} \mathrm{C}$ date (calibrated age $51.2 \mathrm{Ky}$ ) taken from further down the core (Nørgaard-Pedersen et al. 2003).

glacial and Holocene development of this almost unexplored area.

\section{Conclusions}

We suggest that a semi-permanent fast-ice cover characterized the region in the early Holocene, and that subsurface Atlantic water penetrated into the deeper troughs of the fjord system. The greatly reduced accumulation rates during the mid-late Holocene are possibly a result of a reduced sediment flux after 9 Kya as ice margins withdrew. The coal-bearing diamicton found at a shallower depth north-east of Prinsesse Dagmar Island may represent a subglacial till pre-dating the early Holocene sediments (>10 Kya). Further offshore, sediment echo sounding records reveal kilometre-sized troughs, with signs of glacial erosion, till deposition and a stratified Holocene glaciomarine fill. These features, together with sediment core data from the slope region of the Wandel Sea, indicate that last glacial advances of the Greenland Ice Sheet from the Independence Fjord system extended onto the mid-outer Wandel Sea shelf. The Wandel Sea slope record reveals an age of about
25-20 Kya for the most prominent ice advance. The available data do not allow us to more precisely estimate an age of the diamictons on the Wandel Sea shelf and east of Prinsesse Dagmar Island.

\section{Acknowledgements}

We extend our thanks to all those that contributed with logistical assistance during the field campaign in May 2006-not least the friendly support of the crew at Station Nord. The kind invitation by Dorthe Dahl-Jensen and Jørgen Peder Steffensen, the ice core group of the University of Copenhagen, to join their flights to and from Station Nord is much appreciated, as was the invitation by Svend Funder and Kurt Kjær, Geological Museum of the University of Copenhagen, to become part of the Arctic Palaeoclimate and Its Extremes (APEX) project-LongTerm: Quaternary Evolution of North Greenland. Niels E. Poulsen (Geological Survey of Denmark and Greenland) is thanked for his assistance with palynological investigations. This contribution is a result of the EU GreenICE (no. EUK-2001-00280) and LongTerm/APEX projects. 
(a)

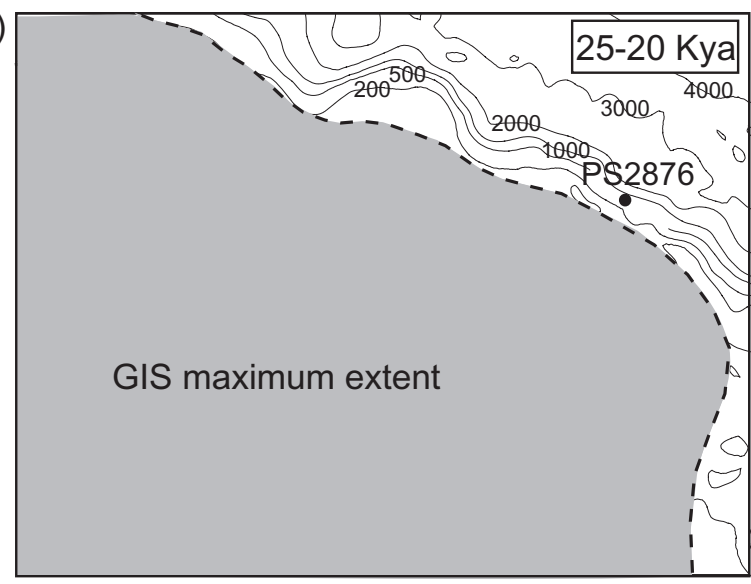

(b)

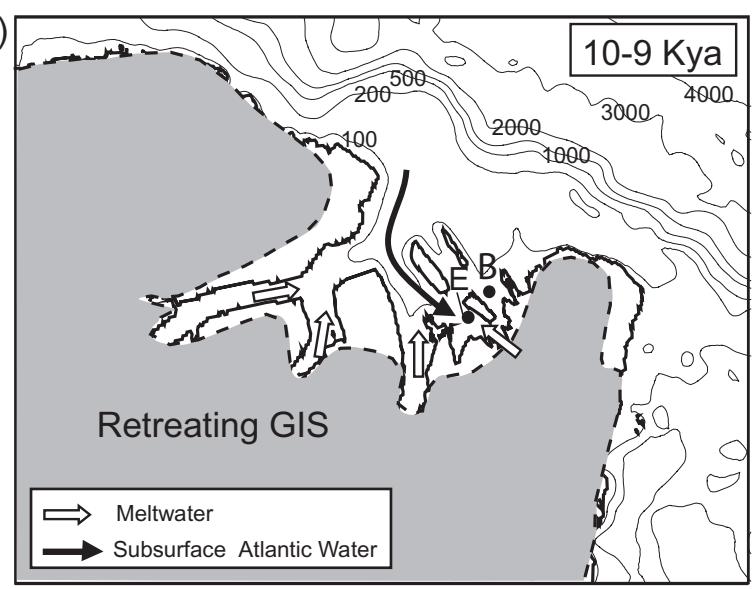

(c)

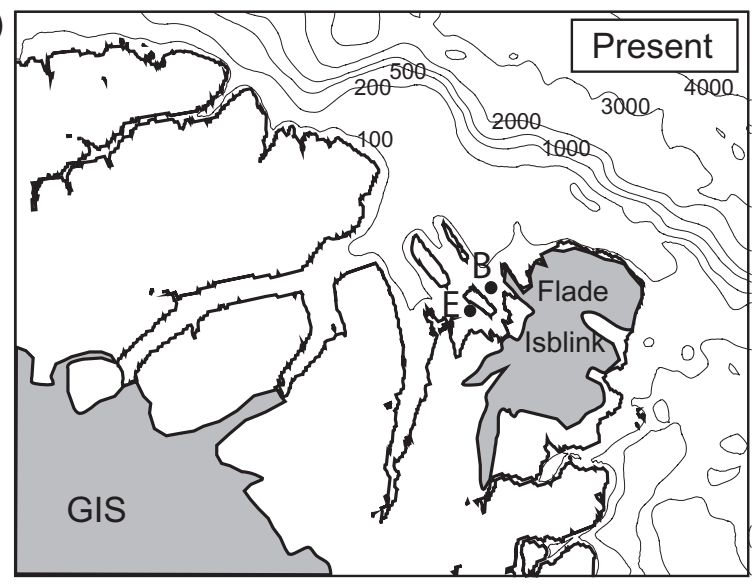

Fig. 9 Tentative ice extents for (a) the Last Glacial Maximum (25-20 Kya) and (b) the early Holocene (10-9 Kya), and (c) the ice extent for present day. The isobaths indicated for the three time slices represent present water levels. The Greenland ice sheet is abbreviated to GIS. Advection of subsurface Atlantic water (black arrow) and influx of meltwater to the Independence Fjord system (white arrows) are indicated for the early Holocene time slice.

\section{References}

Amdrup G.C. 1913. Report on the Danmark Expedition to the north-east coast of Greenland 1906-1908. Meddelelser om Gronland 41. Copenhagen.

Anderson L.G., Björk G., Holby O., Jones E. P., Kattner G., Koltermann K. P., Liljeblad B., Lindegren R., Rudels B. \& Swift J. 1994. Water masses and circulation in the Eurasian Basin: results from the Oden 91 expedition. Journal of Geophysical Research-Oceans 99(C2), 3273-3283.

Bennike O. 1987. Quaternary geology and biology of the Jørgen Brønlund Fjord area, North Greenland. Meddelelser om Gronland Geoscience 18. Copenhagen: Danish Polar Center.

Bennike O. \& Björck S. 2002. Chronology of the last recession of the Greenland Ice Sheet. Journal of Quaternary Science 17, 211-219.

Bennike O. \& Weidick A. 2001. Late Quaternary history around Nioghavfjerdsfjordden and Jøkelbugten, north-east Greenland. Boreas 30, 205-227.

Boström K. \& Thiede J. 1984. Ymer-80 Swedish Arctic Expedition. Cruise report for marine geology and geophysics. Meddelanden från Stockholms Universitets Geologiska Institution 260. Stockholm: University of Stockholm.

Darby D.A., Bischof J., Spielhagen R.F., Marshall S.A. \& Herman S.W. 2002. Arctic ice export events and their potential impact on global climate during the late Pleistocene. Paleoceanography 17, 1025, doi: 10.1029/ 2001 PA000639.

Funder S. 1989. Quaternary geology of the ice-free areas and adjacent shelves of Greenland. In R.J. Fulton (ed.): Quaternary geology of Canada and Greenland. Geology of Canada Series 1. Pp. 743-791. Ottawa: Geological Survey of Canada.

Funder S. \& Hansen L. 1996. The Greenland ice sheet-a model for its culmination and decay during and after the last glacial maximum. Geological Society of Denmark Bulletin 42, 137-152.

Funder S., Hjort C., Landvik J.Y., Nam S. \& Stein R. 1998. History of a stable ice margin-East Greenland during the Middle and Upper Pleistocene. Quaternary Science Reviews 17, 77-123.

Hald M. \& Vorren T.O. 1984. Modern and Holocene foraminifera and sediments on the continental shelf off Troms, north Norway. Boreas 13, 133-153.

Hemer M.A., Post A.L., O’Brien P.E., Craven M., Truswell E.M., Roberts D. \& Harris P.T. 2007. Sedimentological signatures of the sub-Amery Ice shelf circulation. Antarctic Science 19, 497-506.

Henriksen N. 1992. Geological map of Greenland: Peary Land (Sheet 8). (With descriptive text.) Copenhagen: Geological Survey of Greenland.

Hughen K.A., Baillie M.G.L., Bard E., Bayliss A., Beck J.W., Bertrand C., Blackwell P.G., Buck C.E., Burr G., Cutler K.B., Damon P.E., Edwards R.L., Fairbanks R.G., Friedrich M., Guilderson T.P., Kromer B., McCormac F.G., Manning S., Bronk Ramsey C., Reimer P.J., Reimer R.W., Remmele S., Southon J.R., Stuiver M., Talamo S., Taylor F.W., van Der Plicht J. \& Weyhenmeyer C.E. 2004. Marine04 marine 
radiocarbon age calibration, 0-26 cal kyr BP. Radiocarbon 46, 1059-1086.

Håkansson E. \& Pedersen S.A.S. 2001. The Wandel Hav Strike-Slip Mobile Belt-A Mesozoic plate boundary in North Greenland. Geological Society of Denmark Bulletin 48, 149-158.

Jakobsson M. \& Cherkis N. (compilers) 2001. International bathymetric chart of the Arctic Ocean. Version 1.0. Available on the internet at www.ngdc.noaa.gov/mgg/bathymetry/ arctic/arctic.html.

Jakobsson M., Cherkis N.Z., Woodward J., Coakley B. \& Macnab R. 2000. A new grid of Arctic bathymetry: a significant resource for scientists and mapmakers. EOS, Transactions of the American Geophysical Union 81, 89, 93, 96.

Jennings A.E., Weiner N.J., Helgadottir G. \& Andrews J.T. 2004. Modern foraminiferal faunas of the southwestern to northern Iceland shelf: oceanographic and environmental controls. Journal of Foraminiferal Research 34, 180-207.

Koch L. 1928a. The physiography of North Greenland. In M. Vahl et al. (eds.): Greenland. Vol. 1. The Discovery of Greenland. Pp. 491-518. Copenhagen: C.A. Reitzel.

Koch L. 1928b. Contributions to the glaciology of North Greenland. Meddelelser om Grønland 65, 181-464.

Korsun S., Hald M., Panteleeva N. \& Tarasov G. 1998. Biomass of foraminifera in the St. Anna Trough, Russian Arctic continental margin. Sarsia 83, 419-431.

Krause G. (ed.) 1998. The expedition ARKTIS-XIII/3 of RV "Polarstern" in 1997. Berichte zur Polarforschung 262.

Lubinski D.J., Polyak L. \& Forman S.L. 2001. Freshwater and Atlantic water inflows to the deep northern Barents and Kara seas since ca $13{ }^{14} \mathrm{C}$ ka: foraminifera and stable isotopes. Quaternary Science Reviews 20, 1851-1879.

McCave I.N., Manighetti B. \& Robinson S.O. 1995. Sortable silt and sediment size/composition slicing: parameters for paleocurrent speed and paleoceanography.

Paleoceanography 10, 593-610.

Nørgaard-Pedersen N. 1998. Marine gelogical investigations of the northern Fram Strait during ARK XIII/3. In Krause, G. (ed.): The expedition ARKTIS-XIII/3 of RV "Polarstern" in 1997. Berichte zur Polarforschung 262, 17-23.
Nørgaard-Pedersen N., Spielhagen R.F., Erlenkeuser H., Grootes P.M., Heinemeier J. \& Knies J. 2003. Arctic Ocean during the Last Glacial Maximum: Atlantic and polar domains of surface water mass distribution and ice cover. Paleoceanography 18, 1063, doi: 10.1029/2002PA000781.

Ó Cofaigh C. \& Dowdeswell J.A. 2001. Laminated sediments in glacimarine environments: diagnostic criteria for their interpretation. Quaternary Science Reviews 20, 1411-1436.

Polyak L. \& Solheim A. 1994. Late- and postglacial environments in the northern Barents Sea west of Franz Josef Land. Polar Research 13, 197-207.

Reeh N. 1989. Dynamic and climatic history of the Greenland Ice Sheet. In R.J. Fulton (ed.): Quaternary geology of Canada and Greenland. Geology of Canada Series 1. Pp. 794-822. Ottawa: Geological Survey of Canada.

Reeh N., Thomsen H.H., Olesen O.B. \& Starzer W. 1997. Mass balance of North Greenland. Science 278, 207-209.

Rudels B., Jones E.P., Anderson L.G. \& Kattner G. 1994. On the intermediate depth waters of the Arctic Ocean. In O.M. Johannessen et al. (eds.): The polar oceans and their role in shaping the global environment. Geophysical Monograph 85. Pp. 33-46, Washington, DC: American Geophysical Union.

Salvi C., Busetti M., Marinoni L. \& Brambati A. 2006. Late Quaternary glacial marine to marine sedimentation in the Pennell Trough (Ross Sea, Antarctica). Palaeogeography, Palaeoclimatology, Palaeoecology 231, 199-214.

Stein R. \& Fahl K. 1997. Scientific Cruice Report of the Arctic Expedition ARK-XIII/2 of RV "Polarstern" in 1997. Berichte zur Polarforschung 255.

Stuiver M. \& Reimer P.J. 1993. Extended ${ }^{14} \mathrm{C}$ data base and revised CALIB 3.0 14C Age calibration program. Radiocarbon 35, 215-230.

Syvitski J.P.M., Andrews J.T. \& Dowdeswell J.A. 1996. Sediment deposition in an iceberg-dominated glacimarine environment, East Greenland: basin fill implications. Global and Planetary Change 12, 251-270.

Tauber H. \& Funder S. 1975: ${ }^{14} \mathrm{C}$ content of recent molluscs from Scoresby Sund, central East Greenland. Grønlands Geologiske Undersøgelse Rapport 75, 95-99. 